\title{
Analisa Pengaruh Jumlah Urea dan Holding Time Proses Powder Nitriding terhadap Ketahanan Aus Material FC 25
}

\author{
Umen Rumendi, Achmad Muhammad, Mohamad Gheo Wiriaputra \\ Politeknik Manufaktur Bandung
}

Email:umen@polman-bandung.ac.id

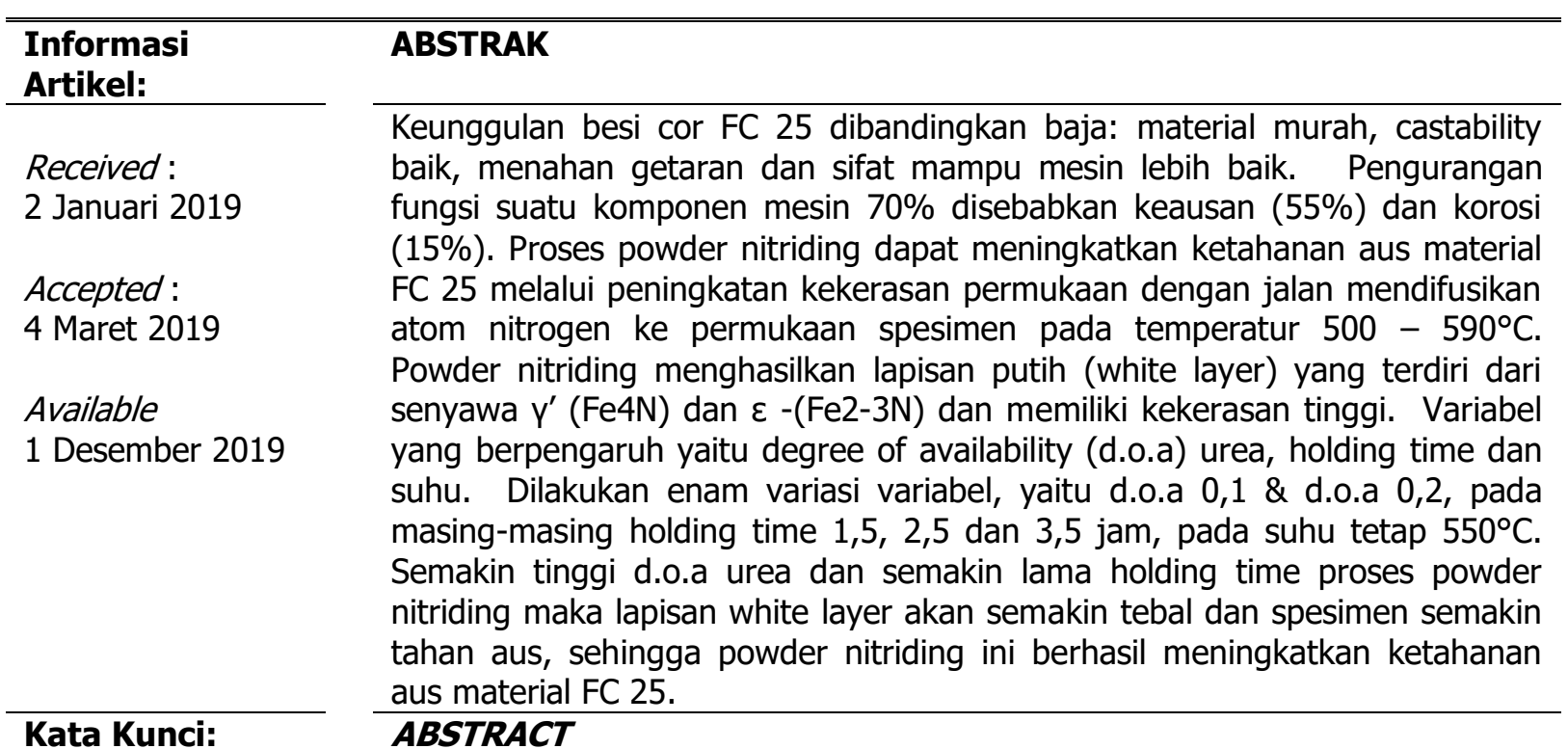

\begin{tabular}{l}
\hline Kata Kunci: \\
\hline Keunggulan besi \\
cor \\
Keausan \\
Powder Nitriding \\
D.o.a \\
Holding Time \\
White Layer \\
Kehilangan berat
\end{tabular}

The advantages of FC 25 cast iron over steel: low-cost material, good castability, better vibration resistance and machinability. Reduction in the function of an engine component is $70 \%$ due to wear and tear (55\%) and corrosion (15\%). The powder nitriding process can increase the wear resistance of FC 25 material by increasing surface hardness by diffusing nitrogen atoms to the surface of the specimen at a temperature of 500 $590^{\circ} \mathrm{C}$. The powder nitriding produces a white layer consisting of the compound $Y$ (Fe4N) and $\varepsilon-(\mathrm{Fe} 2-3 \mathrm{~N})$ and has a high hardness. The influential variables are degree of availability (d.o.a) urea, holding time and temperature. Six variable variations were carried out, namely d.o.a 0,1 \& d.o.a 0,2, at each holding time of 1.5, 2.5 and 3.5 hours, at a constant temperature of $550^{\circ} \mathrm{C}$. The higher d.o.a urea and the longer holding time of the powder nitriding process, the white layer will be thicker and the specimens are more resistant to wear, so that this nitriding powder successfully increases the wear resistance of FC 25 material. 


\section{PENDAhUlUAN}

Perkembangan ilmu pengetahuan dan teknologi saat ini membawa dampak yang begitu besar bagi perkembangan teknologi seiring dengan kemajuan dunia industri, terutama industri yang bergerak dibidang otomotif dan permesinan. Berbagai kebutuhan akan material telah memaksa manusia untuk berinovasi. Sehingga material yang paling banyak digunakan di dunia industri adalah baja, karena baja adalah material yang memiliki sifat mampu dikeraskan yang baik dan relatif ulet. Seiring perkembangan waktu, penggunaan material baja diimbangi dengan penggunaan material besi cor. Hal ini terjadi karena besi cor memiliki beberapa keunggulan dibandingkan baja, yaitu material yang relatif lebih murah, memiliki sifat mampu cor (castability) yang baik, mehanan getaran lebih baik dari baja dan sifat mampu mesin yang relatif lebih baik dibandingkan dengan baja (De Jesus dkk, 2018).

Dalam dunia industri penggunaan material baja dan besi cor sudah menjadi bahan baku utama dalam pembuatan mesin - mesin yang menunjang proses manufaktur. Dalam kondisi operasinya, komponen mesin memiliki kelemahan yaitu nilai kekerasan yang rendah sehingga menyebabkan kegagalan dalam proses operasinya. Salah satu jenis kegagalan yang sering terjadi adalah keausan. "Keausan dapat didefinisikan sebagai kerusakan progresif pada permukaan material yang disebabkan oleh gerakan relatif terhadap material lain (Bayer, 2004)". Keausan merupakan faktor penting dalam mengurangi fungsi permesinan termasuk membatasi usia pakai dan performance berbagai komponen mesin, hal ini mengakibatkan peningkatan biaya maintenance. "Pengurangan fungsi suatu komponen mesin $70 \%$ disebabkan oleh kerusakan pada permukaan logam yang meliputi keausan (55\%), dan korosi (15\%).

Mekanisme keausan yang dominan adalah keausan adhesive (25\%) dan abrasive (20\%), sedangkan sisanya disebabkan oleh mekanisme keausan yang lain (Rabinowicz, 1995)". Berdasar pada referensi, keausan merupakan salah satu faktor yang penting sehingga diperlukan usaha untuk meningkatkan sifat mekanis logam terutama ketahanan terhadap keausan. Salah satu cara untuk meningkatkan keausan adalah dengan powder nitriding. Penelitian pada besi cor yang melalui proses powder nitriding bertujuan untuk mendapatkan material yang lebih tahan terhadap keausan. Proses powder nitriding pada besi cor akan meningkatkan kekerasan pada permukaan namun bagian dalamnya tetap ulet sehingga ketahanan aus pada permukaan menjadi lebih baik. Untuk mengetahui ketahanan ausnya, maka dilakukan uji ketahanan aus pada mesin uji keausan horizontal. Penggunaan besi cor FC 25 didasarkan pada pertimbangan beberapa faktor diantaranya material ini dapat diproduksi oleh institusi Politeknik Manufaktur Bandung, harganya yang relatif murah, mudah didapat dan mudah dibentuk dalam proses permesinan. Material besi cor FC 25 yang sudah melalui proses powder nitriding diharapkan akan memiliki ketahanan aus yang lebih baik dan dapat menjadi komponen pengganti material baja khususnya pada dunia industri manufaktur.

\section{METODOLOGI PENELITIAN}

\subsection{Proses Powder Nitriding}

\subsubsection{Persiapan Media Nitridasi}

Pada penelitian ini, powder nitriding menggunakan pupuk urea sebagai sumber nitrogen seperti penelitian yang dilakukan oleh (Setiawan dkk, 2009) yang telah meneliti proses powder nitriding pada FCD 700. 
Adapun rumus derajat ketersediaan urea untuk mendapatkan berat urea dalam satuan gram. Dengan mengetahui luas permukaan spesimen yang akan dinitridasi maka berat urea dapat ditentukan dengan menggunakan rumus derajat ketersediaan urea, sebagai berikut :

$$
\text { Derajat Ketersediaan Urea }=\frac{\text { Berat Urea }(\text { gram })}{\text { Luas Permukaan Nitridasi }\left(\mathbf{m m}^{2}\right)}
$$

Luas permukaan spesimen yang dinitridasi, yaitu luas permukaan balok:

Rumus luas permukaan balok: $(2 x p \boldsymbol{x} l)+(2 x \boldsymbol{p} x \boldsymbol{t})+(2 x \boldsymbol{l} x \boldsymbol{t})$

Perhitungan : $(22 \mathrm{~mm} \times 10 \mathrm{~mm} \times 2)+(22 \mathrm{~mm} \times 7 \mathrm{~mm} \times 2)+(10 \mathrm{~mm} \times 7 \mathrm{~mm} \times 2)=888$ $\mathrm{mm}^{2}$.

Berdasarkan persamaan di atas, untuk derajat urea 0,1 maka berat urea adalah 88,8 gram, sedangkan untuk derajat urea 0.2 maka berat urea adalah 177,6 gram.

\subsubsection{Persiapan Tabung Reaktor}

Tabung reaktor pada penelitian ini merupakan pipa ST 37 dengan dimensi $\varnothing 2$ inci $\times 250 \mathrm{~mm}$ sebanyak 6 pcs. Pada permukaan tabung bagian dalam dilapisi dengan flintkote yang dicampur dengan semen tahan api agar nitrogen tidak terdifusi ke permukaan tabung.

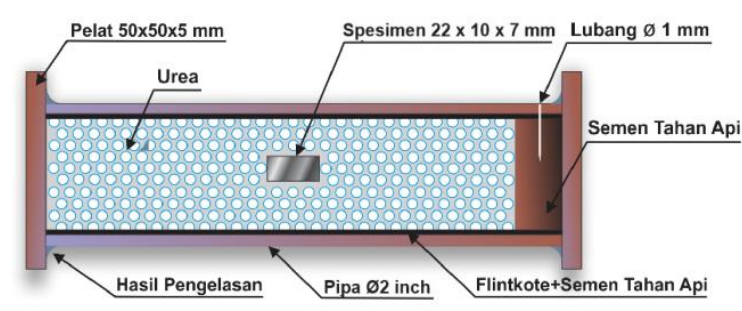

Gambar 1. Tabung Reaktor

\subsection{Pengujian Spesimen}

\subsubsection{Uji Mikrostruktur (Metallography)}

Uji mikrostruktur dilakukan untuk memeriksa morfologi dan ketebalan white layer pada benda yang diuji. Pengujian dilakukan dengan menaruh spesimen pada dudukan spesimen mikroskop optic (lihat gambar 3.2) yang memiliki skala pembesaran dari 100x sampai 2000x (2) dan dilengkapi dengan kamera Image Analyzer Omnimet (3).

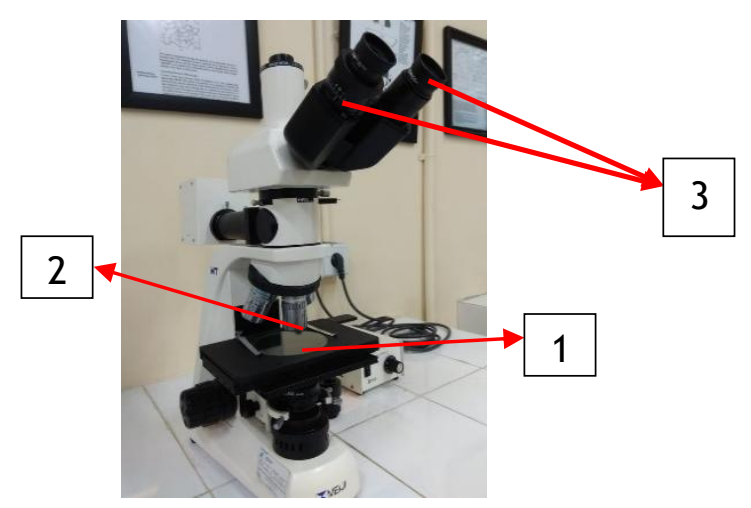

Gambar 2. Mikroskop Uji Struktur 


\subsubsection{Uji Kekerasan}

Uji kekerasan yang dilakukan adalah uji kekerasan brinnel dan uji micro vickers. Uji kekerasan brinnel dilakukan untuk mengetahui kekerasan spesimen awal dengan P sebesar $250 \mathrm{~N}$, sedangkan uji micro vickers dilakukan untuk menguji kekerasan spesimen setelah diproses powder nitriding. Uji micro vickers dilakukan dengan menggunakan beban 200 gram untuk mengetahui distribusi kekerasan pada spesimen yang sudah diproses dan juga untuk mengetahui depth of nitriding yang dilakukan dengan cara memotong benda kerja melintang dan mengukur kekerasan dari sisi terluar hingga sisi terdalam spesimen uji.

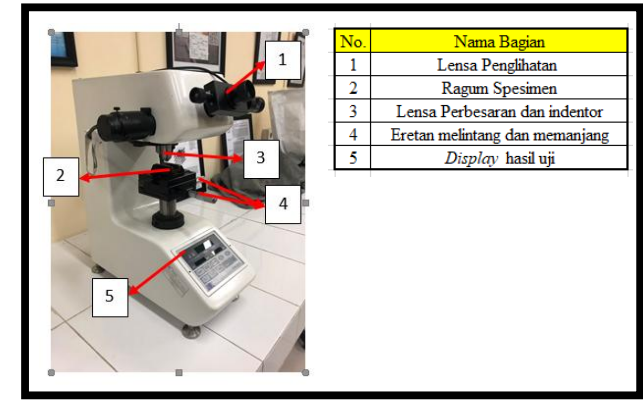

Gambar 3. Mesin Uji Mikro vickers

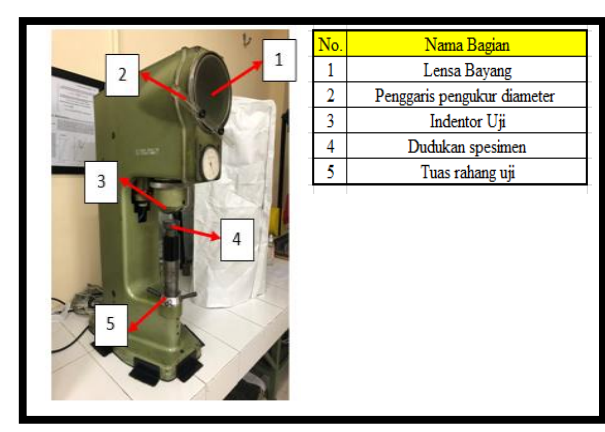

Gambar 4. Mesin Uji Brinnel

\subsubsection{Uji Keausan}

Pengujian keausan dilakukan dengan menggunakan mesin uji keausan. Metode pengujian yang dilakukan yaitu kondisi basah dan kondisi kering dimana prinsip kerjanya adalah sebagai berikut:

1. Kecepatan putar steel disc (1) yaitu 320,2 rpm.

2. Beban pengujian (2), yaitu $1,8 \mathrm{~kg}$.

3. Pengujian dilakukan dalam dua kondisi, yaitu pengujian basah dan kering. Pengujian basah menggunakan oli sebagai media uji dan dioleskan secara merata pada landasan gesekan sebelum pengujian dilakukan. Pengujian kering dilakukan tanpa menggunakan media apapun.

4. Waktu pengujian keausan kondisi basah yaitu 5 jam per spesimen dengan melakukan penimbangan pada setiap 1 jam pengujian, sementara untuk pengujian keausan kondisi kering yaitu 2 jam per spesimen dengan melakukan penimbangan pada setiap 0,5 jam pengujian. Panjang track untuk pengujian basah $42,227 \mathrm{~km}$, sementara panjang track untuk pengujian kering $16,891 \mathrm{~km}$. 


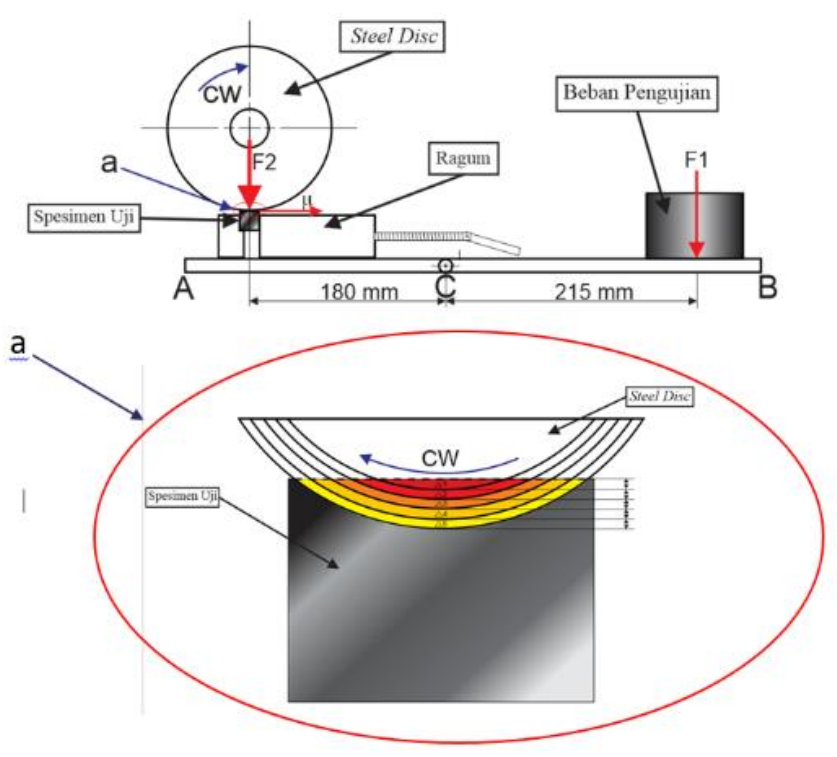

Gambar 5. Diagram benda bebas untuk gaya yang diterima oleh spesimen uji keausan

\section{HASIL DAN PEMBAHASAN}

\subsection{Hasil Pengujian Spesimen Awal}

\subsubsection{Hasil Uji Kekerasan Spesimen Awal}

Uji Kekerasan yang dilakukan pada spesimen awal adalah uji kekerasan brinnel dan uji kekerasan mikro vickers. Pengujian ini dilakukan pada spesimen FC25 yang belum melalui proses powder nitriding pada lima titik yang berbeda. diperoleh nilai kekerasan material FC 25 memiliki rata-rata kekerasan sebesar 201,8966 HB dan 181,64 HV dengan beban 200 gram.

\subsubsection{Hasil Uji Mikro Struktur Spesimen Awal}

Uji mikro struktur dilakukan untuk mengetahui struktur awal material dan memastikan bahwa material yang dipakai adalah FC yang memiliki grafit lamellar, berikut hasil mikro struktur awal:

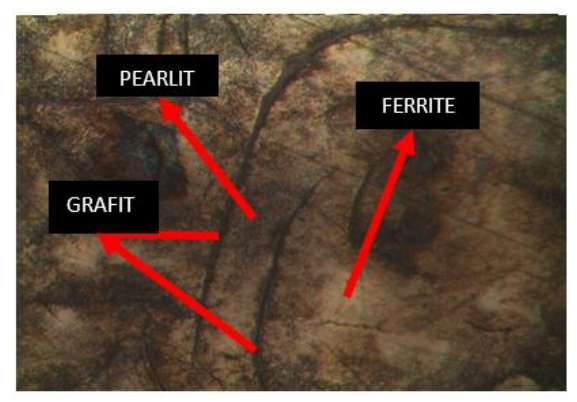

Gambar 6. Mikro struktur FC 25

Gambar di atas merupakan hasil uji mikro struktur spesimen awal FC 25 dengan perbesaran 1000x menunjukan adanya ferrite dan batas butir pearlite. Pearlite merupakan kombinasi besi- $\propto$ dan karbon $(\propto+\mathrm{Fe} 3 \mathrm{C})$. Karakteristik fasa ini menghasilkan sifat keras sehingga memiliki karakteristik pearlite. 


\subsection{Hasil Pengujian Spesimen Nitriding}

Pada tahap ini, terdapat enam spesimen yang sudah melalui proses powder nitriding dengan variabel sebagai berikut :

Tabel 1. Variabel Penelitian Powder Nitriding

\begin{tabular}{|c|c|c|}
\hline \multicolumn{3}{|c|}{ Variabel Penelitian Powder Nitriding } \\
\hline No & Derajat Ketersediaan Urea (D.O.A) & Waktu \\
\hline 1 & 0,1 & $1,5 \mathrm{jam}$ \\
\hline 2 & 0,1 & $2,5 \mathrm{jam}$ \\
\hline 3 & 0,1 & $3,5 \mathrm{jam}$ \\
\hline 4 & 0,2 & $1,5 \mathrm{jam}$ \\
\hline 5 & 0,2 & $2,5 \mathrm{jam}$ \\
\hline 6 & 0,2 & $3,5 \mathrm{jam}$ \\
\hline
\end{tabular}

Variabel penelitian ini didasarkan pada penelitian yang dilakukan tahun 2009 dengan judul "PENGARUH TEMPERATUR DAN WAKTU PROSES NITRIDASI TERHADAP KEKERASAN PERMUKAAN FCD 700 DENGAN MEDIA NITRIDASI UREA" (Setiawan \& Purwadi, 2009). Penelitian tersebut menggunakan variabel waktu 1 jam dan 2 jam; suhu yang bervariasi dari $530^{\circ} \mathrm{C}$ sampai $620^{\circ} \mathrm{C}$ dan d.o.a merupakan variabel tetap, yaitu 0,1 . Sementara penelitian ini menggunakan d.o.a 0,1 dan 0,2; waktu yang bervariasi dari 1,5 jam sampai 3,5 jam dan suhu merupakan variabel tetap, yaitu $550^{\circ} \mathrm{C}$. Perbedaan variabel ini dilakukan agar memperoleh analisa berupa pengaruh dari perubahan d.o.a dan waktu yang terjadi pada difusi powder nitriding terhadap material FC 25.

\subsubsection{Hasil Uji Mikro Vickers Spesimen Pasca Nitriding}

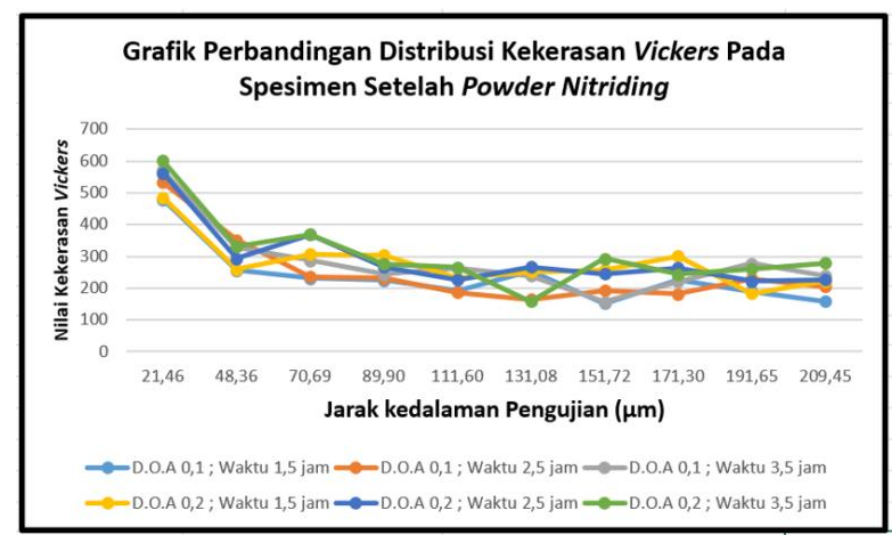

Gambar 7. Grafik Distribusi Kekerasan Vickers

Berdasarkan pada gambar 7 dapat dilihat bahwa kekerasan vickers tertinggi berada pada titik yang berjarak rata - rata $21,46 \mu \mathrm{m}$ dari luar permukaan spesimen uji yang merupakan white layer dimana kekerasan terbesar didapatkan dari powder nitriding dengan variabel d.o.a 0,2 ; holding time 3,5 jam yaitu $601 \mathrm{HV}$, sementara kekerasan white layer yang paling rendah berada pada variabel d.o.a 0,1; holding time 1,5 jam yaitu 478,6 HV. Untuk nilai kekerasan vickers yang berada pada titik rata - rata 48,36 $\mu \mathrm{m}$ sampai 209,45 $\mu \mathrm{m}$ dari luar permukaan spesimen memiliki nilai kekerasan diantara 152,6 HV sampai dengan 368,8 HV, porositas yang tinggi dari material FC 25 membuat adanya difusi white layer ke bagian dalam spesimen sehingga kekerasan pada bagian tersebut berada di sekitar nilai $300 \mathrm{HV}$. 


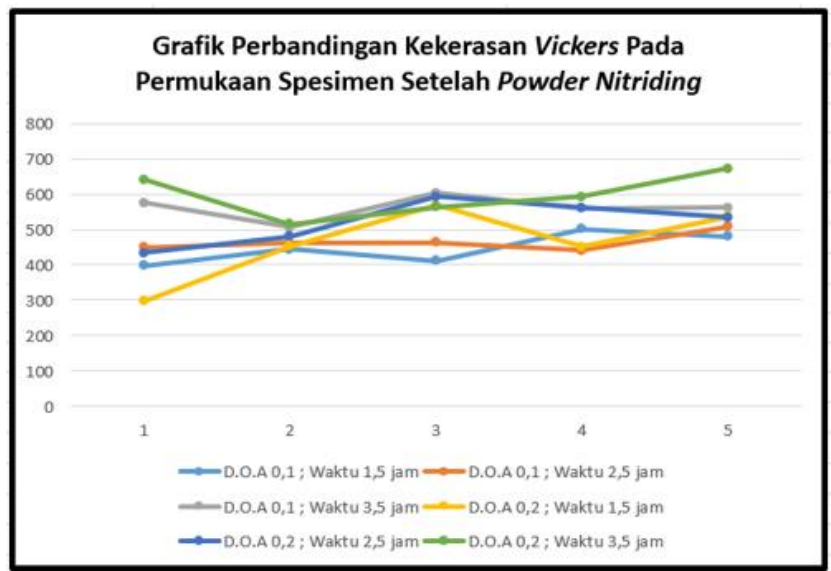

Gambar 8. Grafik Kekerasan Vickers Pada Permukaan Spesimen

Dilihat dari gambar 8 rata - rata kekerasan vickers pada permukaan spesimen yang tertinggi berada pada variabel d.o.a 0,2 ; holding time 3,5 jam yaitu 596,7 HV, sementara yang terendah berada pada variabel d.o.a 0,1 ; holding time 1,5 jam yaitu 446,72 HV, hal ini membuktikan bahwa semakin besar d.o.a dan semakin lama holding time membuat kekerasan white layer semakin tinggi.

\subsubsection{Hasil Uji Mikro Struktur Spesimen Powder Nitriding}

Berikut hasil uji mikro struktur yang dilakukan :

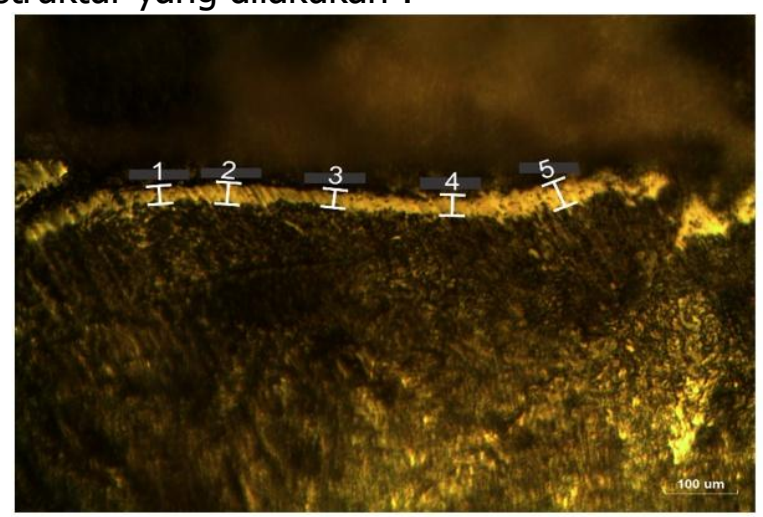

Gambar 9. Uji mikro struktur d.o.a 0,1; holding time 1,5 jam

Pada hasil uji struktur mikro dengan perbesaran 2000 kali didapatkan ketebalan rata-rata white layer adalah 3,24 $\mu \mathrm{m}$. 


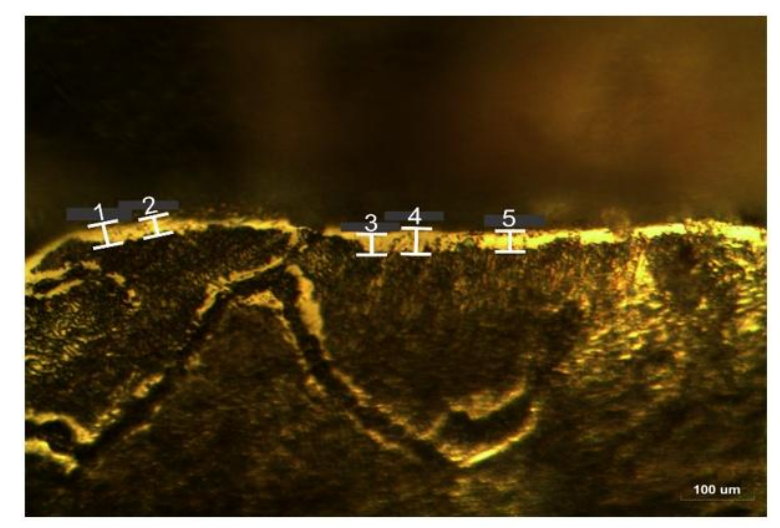

Gambar 10. Uji mikro struktur d.o.a 0,1; holding time 2,5 jam

Pada hasil uji struktur mikro dengan perbesaran 2000 kali didapatkan ketebalan rata-rata white layer adalah 3,314 $\mu \mathrm{m}$.

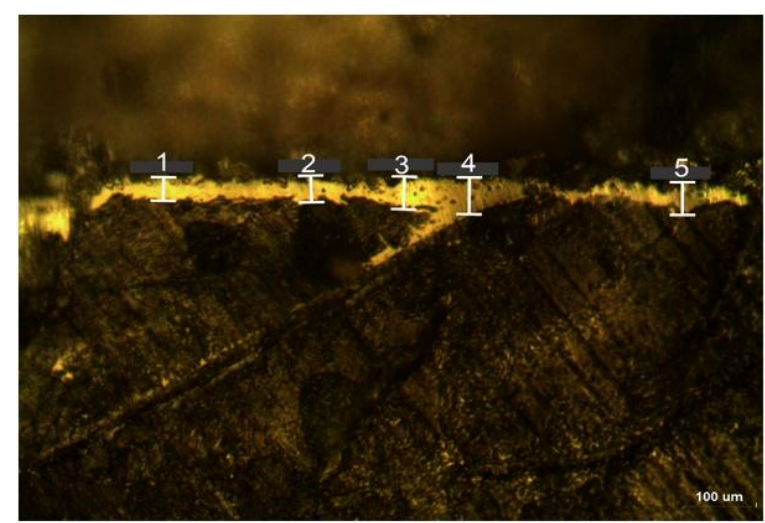

Gambar 11. Uji mikro struktur d.o.a 0,1; holding time 3,5 jam Pada hasil uji struktur mikro dengan perbesaran 2000 kali didapatkan ketebalan rata-rata white layer adalah 4,584 $\mu \mathrm{m}$.

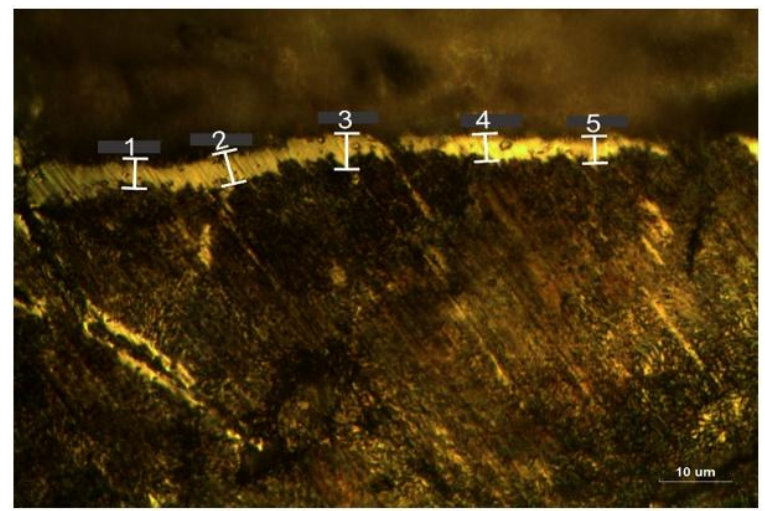

Gambar 12. Uji mikro struktur d.o.a 0,2 ; holding time 1,5 jam

Pada hasil uji struktur mikro dengan perbesaran 2000 kali didapatkan ketebalan rata-rata white layer adalah 4,668 $\mu \mathrm{m}$. 


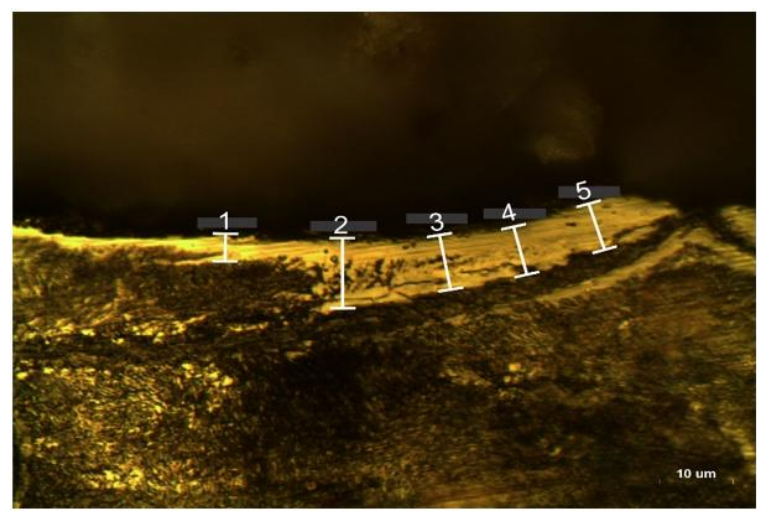

Gambar 13. Uji mikro struktur d.o.a 0,2 ; holding time 2,5 jam

Pada hasil uji struktur mikro dengan perbesaran 2000 kali didapatkan ketebalan rata-rata white layer adalah 7,686 $\mu \mathrm{m}$.

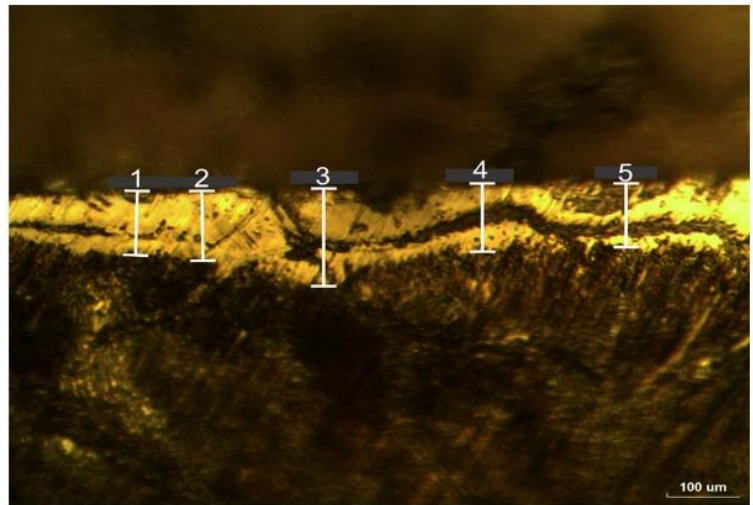

Gambar 14. Uji mikro struktur d.o.a 0,2 ; holding time 3,5 jam

Pada hasil uji struktur mikro dengan perbesaran 2000 kali didapatkan ketebalan rata-rata white layer adalah $11,024 \mu \mathrm{m}$.

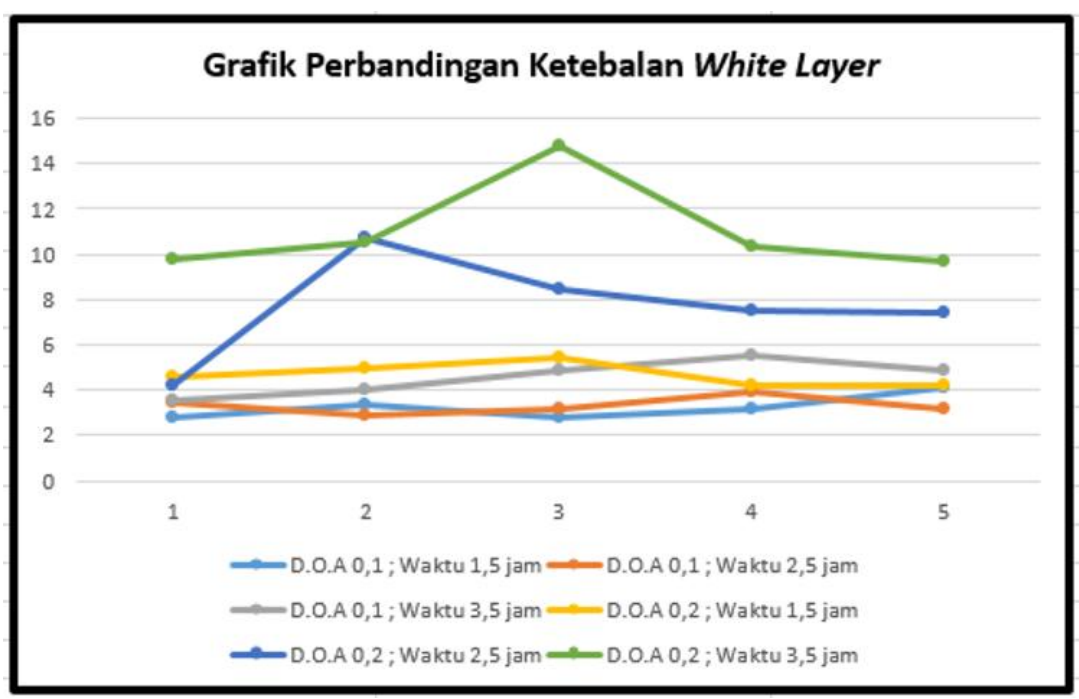

Gambar 15. Grafik Perbandingan Ketebalan White Layer 
Pada gambar 15 ketebalan white layer tertinggi berada pada variabel d.o.a 0,2 ; holding time 3,5 jam dengan ketebalan sebesar $14,78 \mu \mathrm{m}$ pada titik pengukuran ketiga, sementara ketebalan white layer paling rendah berada pada 2,79 $\mu \mathrm{m}$ di titik pengukuran kesatu dan ketiga pada variabel d.o.a 0,1 ; holding time 1,5 jam.

\subsubsection{Hasil Uji Keausan Spesimen}

Berikut hasil uji keausan :

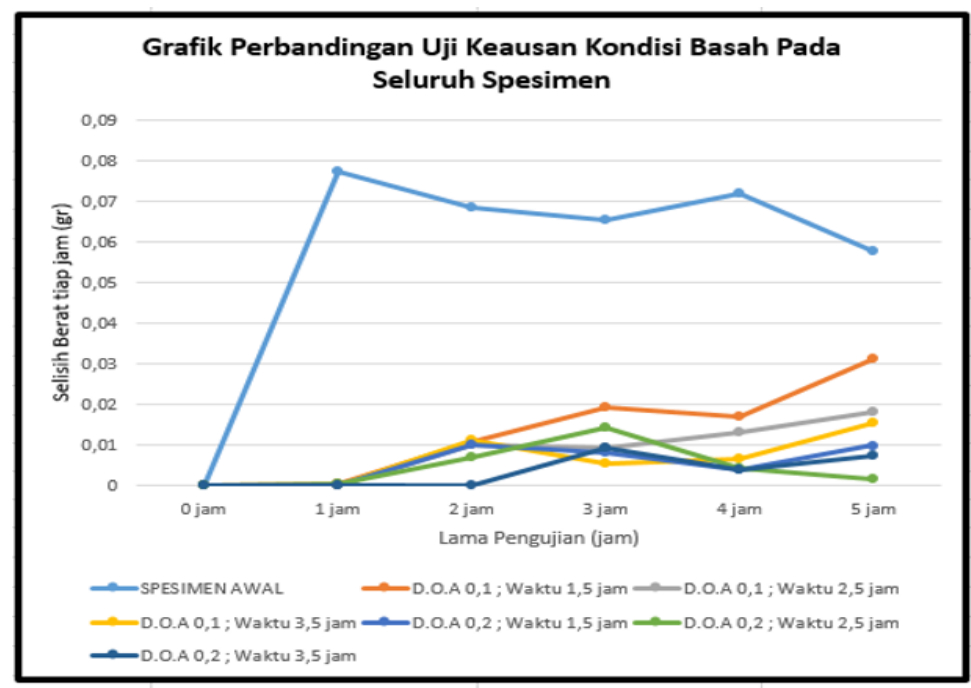

Gambar 16. Grafik Perbandingan Uji Keausan Kondisi Basah Pada Seluruh Spesimen

Berdasarkan gambar 16, selisih berat yang terjadi pada spesimen awal berbeda jauh dengan spesimen pasca nitriding, dimana selisih berat tiap jam terbesar berada pada spesimen awal dengan pengujian keausan kondisi basah selama 1 jam yaitu 0,0772 gram dan selisih berat tiap jam terkecil berada pada variabel d.o.a 0,2 ; holding time 3,5 jam dengan pengujian kondisi basah selama 1 jam yaitu 0,0000 gram, dimana selisih berat yang terjadi pada variabel ini tidak terukur dengan timbangan berat per 10.000. Pada jam berikutnya dapat dilihat bahwa perbedaan selisih berat tiap jam yang terjadi pada spesimen awal sangat berbeda jauh dengan spesimen pasca nitriding.

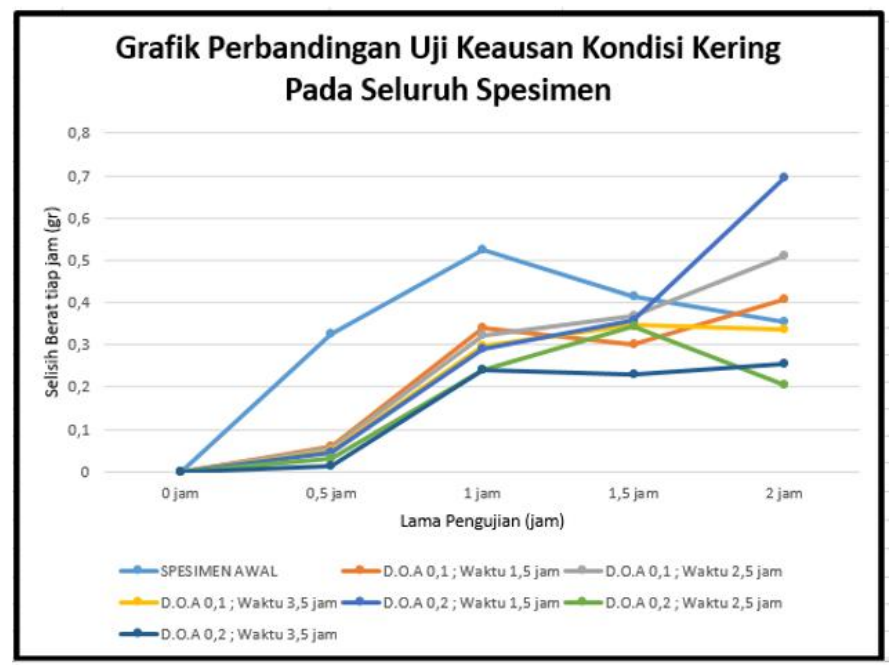

Gambar 17. Grafik Perbandingan Uji Keausan Kondisi Kering Pada Seluruh Spesimen 
Dapat dilihat pada gambar 17, selisih berat yang terjadi pada pengujian spesimen awal berbeda jauh dengan spesimen pasca nitriding pada pengujian keausan kondisi kering selama 0,5 jam, dimana selisih berat pada spesimen awal yaitu 0,3259 gram sementara selisih berat terkecil berada pada variabel d.o.a 0,2 ; holding time 3,5 jam yaitu 0,0131 gram. Pada pengujian selanjutnya selisih berat yang terjadi pada spesimen pasca nitriding mulai semakin mendekati nilai pengujian pada spesimen awal dikarenakan white layer telah habis terkikis.

\subsection{Pengaplikasian FC 25 Pasca Nitriding Dalam Dunia Manufaktur}

Pengaplikasian FC 25 pada dunia manufaktur sangat banyak, untuk benda kerja yang sering mengalami gesekan contohnya adalah guide bush, ring piston dan clutch drum. Guide bush dan ring piston dalam kondisi aktualnya mengalami gesekan kondisi basah karena menggunakan oli untuk menghambat laju keausannya. Sementara clutch drum dalam kondisi aktualnya tidak menggunakan media apapun untuk menghambat laju keausannya atau keausan kondisi kering. Berdasarkan letak gesekan (friction) dari gambar di atas, powder nitriding dapat diaplikasikan pada bagian permukaan yang terkena kontak secara langsung dengan gaya gesek yang terjadi untuk meningkatkan ketahan aus pada permukaan tersebut.

\section{KESIMPULAN}

Dari penelitian yang telah dilakukan, dapat ditarik kesimpulan sebagai berikut :

1. Semakin tinggi d.o.a (degree of availability) urea dan semakin lama holding time proses powder nitriding, maka lapisan white layer yang terbentuk semakin tebal. D.o.a 0,2 ; holding time 3,5 jam memiliki tebal white layer 11,024 $\mathbf{\mu m}$ sedangkan d.o.a 0,1 ; holding time 1,5 jam memiliki tebal white layer 3,24 $\mathbf{\mu m}$.

2. Semakin tinggi d.o.a urea dan semakin lama holding time proses powder nitriding, maka ketahanan aus material akan semakin kuat dan selisih berat yang terjadi berbeda jauh dengan spesimen awal. D.o.a 0,2 ; holding time 3,5 jam kehilangan berat sebesar 0,0036 gram/ jam pada pengujian keausan basah dan 0,1472 gram/0,5 jam pada pengujian keausan kering, d.o.a 0,1 ; holding time 1,5 jam kehilangan berat sebesar 0,0131 gram/jam pada pengujian keausan basah dan 0,2215 gram/0,5 jam pada pengujian keausan kering, spesimen awal kehilangan berat sebesar 0,0568 gram/ jam pada pengujian keausan basah dan 0,3243 gram/0,5 jam pada pengujian keausan kering. Terlihat perbedaan laju keausan yang signifikan dari spesimen pasca nitriding dengan spesimen awal.

3. Variabel yang paling optimal adalah derajat ketersediaan urea 0,2 dan waktu 3,5 jam.

4. Pengaplikasian powder nitriding ini dapat ditujukan untuk guide bush, ring piston dan clutch drum.

\section{REFERENSI}

[1]. Annafida. (2012, Maret 7). Retrieved from https://blog.ub.ac.id/annafida/2012/ 03/07/diagram-fasa-fe-fe3c/

[2]. Bayer, R. G. (2004). Mechanical Wear Fundamentals and Testing. New York.

[3]. De Jesus, A. D., \& Soebiyakto, G. (2018). ANALISIS UJI TARIK DAN METALOGRAFI SIFAT MEKANIK BESI TUANG KELABU (FC-20) DENGAN PROSES HEAT TREATMENT.

[4]. Gnedovets, A. G., Ankudinov, A. B., Zelenskii, V. A., Kovalev, E. P., WisnieskaWeinert, H., \& Alymov, M. I. (2015). Synthesis of Micron Particles with Fe-Fe4N 
Core-Shell Structure at Low-Temperature Gaseous Nitriding of Iron Powder in a Stream of Ammonia.

[5]. Iriawan, A. (2016). Proses Pengerjaan Logam Surface Hardening.

[6]. Permana, T. S., \& Rumendi, U. (2014). ANALISA UJI KEAUSAN MATERIAL St 37 HASIL CARBURIZING DAN HARDENING DENGAN MENGGUNAKAN MESIN UJI KEAUSAN HORIZONTAL. STEMAN 2014 ISBN 978-979-17047-5-5.

[7]. Rabinowicz, E. (1995). Friction and Wear of Material. Singapore: John Willey \& Sons, Inc.

[8]. Sandi, P. (2006). Powder Nitriding pada Baja Karbon Rendah dengan Menggunakan Urea.

[9]. Setiawan, A. B., \& Purwadi, W. (2009). PENGARUH TEMPERATUR DAN WAKTU PROSES NITRIDASI TERHADAP KEKERASAN PERMUKAAN FCD 700 DENGAN MEDIA NITRIDASI UREA.

[10]. Sucandra, A. (2014). Pupuk Urea.

[11]. Suratman, R. (1994). Panduan Proses Perlakuan Panas. Lembaga Penelitian Institut Teknologi Bandung.

[12]. Teckhuat. (2015). Teck Huat Hardware (Pte) Ltd. Retrieved from www.teckhuat.com

[13]. Thelning, K.-E. (1981). Steel and Its Heat Treatment Bofors Handbook. Maskinaktiebolaget Karlebo.

[14]. Widodo, R. (2012). Komposisi Besi Cor.

[15]. Yang, Z. (2013). The Use of Nitriding to Enhance Wear Resistance of Cast Irons and 4140 Steel.

[16]. Yannuar, S. (2014). Besi Tuang. Yogyakarta. 